\title{
Unaccompanied/Separated Minors and Refugee Protection in Canada: Filling Information Gaps
}

\author{
Judith Wouk, Soojin Yu, Lisa Roach, Jessie Thomson, and Anmarie Harris
}

\begin{abstract}
This paper fills information gaps with regard to unaccompanied/separated minors in Canada. By the means of reviewing Citizenship and Immigration Canada administrative databases, it investigates how many unaccompanied/separated refugee minors exist, who they are, and how they are received in Canada. We found that there were fewer truly unaccompanied minors than previously reported. In the asylum stream, only 0.63 per cent (or 1,087) of the total claimant population were found to be unaccompanied by adults in the past five years. In the resettlement stream only two truly unaccompanied minors were resettled during 2003 and 2004. Regarding their socio-demographic characteristics, we found that unaccompanied minors compose a highly heterogeneous group from many different countries.

Regarding how they were received in Canada, very little evidence existed. Our study found that unaccompanied and separated asylum-seeking minors showed a higher acceptance rate and quicker processing times than the adult population, but details about the minors' actual reception into Canada remains to be further explored.

This study recommends that Citizenship and Immigration Canada review its administrative databases with a view toward improving the data about separated/unaccompanied children. Consistent and detailed definitions are required to develop a comprehensive policy framework for unaccompanied/separated minor refugees in Canada.
\end{abstract}

\section{Résumé}

L'article remplit quelques failles d'information relativement aux mineurs séparés/non accompagnés au Canada. En s'appuyant sur l'analyse de bases de données administratives de Citoyenneté et Immigration Canada, l'article se penche sur le nombre réel de réfugiés mineurs séparés/non accompagnés, qui ils sont et comment ils sont accueillis au Canada. Il en résulte un nombre moins élevé de mineurs réellement non accompagnés que le nombre diffusé antérieurement. Parmi le flot de réfugiés, seulement 0,63 pour cent (ou 1 087) de l'ensemble de la population requérante était non accompagné par des adultes au cours des cinq dernières années. Dans l'ensemble des réinstallations, seulement deux mineurs vraiment non accompagnés ont fait l'objet d'une relocalisation en 2003 et 2004. À l'égard de leur particularités socio-démographiques, l'étude a démontré que les mineurs non accompagnés formaient un groupe hautement hétérogène issu de nombreux pays différents.s

Il existe peu de traces de la façon dont ils ont été accueillis au Canada. L'étude révèle que les demandes d'asile parmi les mineurs séparés et non accompagnés sont davantage acceptées et jouissent d'un temps de traitement plus court que parmi la population adulte. Toutefois, une analyse détaillée sur l'accueil réel des mineurs au Canada reste à faire.

L'article recommande que Citoyenneté et Immigration Canada revoit ses bases de données administratives avec l'objectif de mettre à jour les renseignements sur les enfants séparés/non accompagnés. Il est nécessaire d'avoir des définitions cohérentes et détaillées pour établir un cadre politique global à l'égard des mineurs séparés/non accompagnés au Canada. 


\section{Introduction}

While a substantial body of literature on unaccompanied/separated children asylum seekers exists in Europe, surprisingly little has been published about their counterparts in Canada. Moreover, most of the existing publications by scholars and non-governmental organizations (NGOs) start by lamenting the lack of reliable data in Canada. ${ }^{1}$ This has led to requests from national and international sources to provide statistics in order to develop a consistent national policy on the reception and care of unaccompanied/separated children in the refugee protection stream. For example, the Concluding Observations of the UN Convention on the Rights of the Child monitoring committee 2003 is especially concerned about the absence of a definition of "separated child" and the lack of reliable data on asylum-seeking children. ${ }^{2}$ This paper addresses these gaps. It explores the inconsistencies and inadequacies in administrative databases of Citizenship and Immigratino Canada (CIC) with regard to unaccompanied/separated minors and investigates the following questions: How many unaccompanied/separated refugee minors are there in Canada? Who are they? How are they received once they arrive in Canada? In so doing, we hope to help identify the current challenges and policy priorities for the future.

The paper will first present a brief introduction to the two strands of Canada's refugee protection program (inCanada asylum and overseas resettlement) in the context of protecting minor refugees, followed by a summary of the debates surrounding the definition of unaccompanied/separated minors. This section includes the definitions and terminology adopted for the purpose of this paper. Substantive findings will follow separately for the asylum-seeking minors and resettled minors. Finally, the paper ends with a brief summary and concluding remarks.

\section{Canada's Refugee Protection System and Unaccompanied/Separated Minors}

In keeping with its humanitarian tradition and international obligations, Canada provides protection to thousands of people every year through our refugee protection system. ${ }^{3}$ All policies and programs relating to unaccompanied/separated children refugees are created and administered in accordance with the 2002 Immigration and Refugee Protection Act (IRPA) ${ }^{4}$ as well as the Canadian Constitution, including the Charter of Rights and Freedoms, the Privacy Act, and other domestic legislation where appropriate. Internationally, Canada is a signatory to the 1951 Convention relating to the Status of Refugees, ${ }^{5}$ the Convention on the Rights of the Child, ${ }^{6}$ and other international legal instruments.
Canada's refugee protection system consists of two main components: the In-Canada Refugee Protection Process, for persons making refugee protection claims from within Canada, and the Refugee and Humanitarian Resettlement Program, for people seeking protection from outside Canada.

\subsection{In-Canada Refugee Protection Process}

Canada offers protection to people in Canada who have a well-founded fear of persecution for reasons of race, religion, nationality, membership in a particular social group or political opinion, or a danger of torture or risk to life or cruel and unusual treatment or punishment in their country of nationality. A claim for protection in Canada can be made at a port of entry or at a CIC office. An officer will determine whether a refugee protection claimant is eligible to be referred to the Immigration and Refugee Board (IRB) for a decision with regard to the risks for the individual upon return. Protection is conferred when the IRB determines that the applicant is a Convention refugee or person in need of protection. Protected persons are eligible for various types of settlement assistance. Unsuccessful claimants enter the removal stream. However, as Canada is committed to ensuring that people are not returned to a country where they would be at risk, most persons under a removal order that is in force can apply for a Pre-Removal Risk Assessment (PRRA). In addition, at any time in the process, an applicant can apply to remain in Canada for humanitarian and compassionate reasons $(\mathrm{H} \& \mathrm{C}){ }^{7}$ In making an $\mathrm{H} \& \mathrm{C}$ decision, the officer is required to take into account the best interests of a child directly affected.

\subsection{Humanitarian Resettlement Program}

Foreign nationals are also able to apply for refugee protection while outside Canada through the Refugee and $\mathrm{Hu}-$ manitarian Resettlement Program. Resettlement involves both the selection of refugees overseas and the settlement assistance necessary to facilitate their subsequent integration in Canada. The Canadian government has several programs to help refugees resettle in Canada and establish themselves in their new home. Government Assisted Refugees (GARs) are referred by UNHCR and supported through the Resettlement Assistance Program. Privately Sponsored Refugees (PSRs) are supported by voluntary sponsoring groups who provide refugees with lodging, care, and settlement assistance.

IRPA enhanced Canada's ability to assist unaccompanied/separated minors by introducing additional flexibility with regard to family composition. ${ }^{8}$ However, CIC realized that a number of Canadian families, who had agreed to act as guardians for refugee minors, were unable to provide the specialized care and attention that these refugee minors needed. As neither the Canadian sponsorship infrastruc- 
ture nor the provincial child welfare services were able to provide the necessary care and protection for these minors, a moratorium on the resettlement of separated minors was pronounced in May 2001, preventing the resettlement in Canada of truly separated minors who are without the care and protection of a bona fide caregiver. ${ }^{9}$

\section{Defining "Unaccompanied/Separated Minors"}

There is a consensus that unaccompanied/separated minor refugees are particularly vulnerable. The consensus breaks down however, when it comes to identifying exactly who these minors are. The widest definition identifies as "unaccompanied" any minor who is not with both parents who have documents, such as birth certificates, marriage licenses, or passports, to prove the relationship. At the other end of the spectrum, the narrowest excludes as accompanied any minor who is with or who expresses the intent to join any adult, such as a parent, uncle, or family friend. For accurate reporting and policy development, not least the minor's safety, it is important to be clear about who falls within the definition. Therefore, based on a literature review, we have identified the following elements that must be clarified in order to define the population in question: who is a minor (age); what does being unaccompanied/separated entail (presence or absence of parents or custodians at specific points in time); and in the absence of parents or legal custodians, who can be considered acceptable caregivers?

First, with regard to age, and as accepted by the Government of Canada, the Convention on the Rights of the Child defines a child as "every human being below the age of eighteen years." This includes anyone before their eighteenth birthday and is sometimes expressed as "seventeen and under." Although this is the definition that is adopted in this paper, it is important to note that the age of majority differs from province to province. For example, a minor child is defined as under nineteen in British Colombia, New Brunswick, Nunavut, Northwest Territories, Nova Scotia, Newfoundland, and Yukon. In Ontario, services to children aged sixteen and seventeen differ from those available to younger children.

Secondly, the presence/absence of relevant adults (parents or guardian or relatives or friends) needs to be taken into consideration. Because migration is a process spanning a period of time rather than a finite event, the presence of adults before arriving in Canada, including time during the travel, and their presence after arrival can be examined separately. For the purpose of this paper, both circumstances are taken into consideration. Another dimension relating to the presence/absence of adults is whether the situation which provoked the separation was "involuntary" (i.e. the child was lost in the confusion of refugee camps or recruited by the military) or "voluntary." 10 This paper will focus on whether or not an adult is or will be present to provide care and protection for the minor in Canada. ${ }^{11}$

Finally, in the absence of parents, the question of who is an acceptable caregiver of the minor is crucial. Most sources agree that minors coming with parents or legal custodians are neither unaccompanied nor separated. However, what about minors coming with relatives? Friends? The UNHCR and NGOs, such as the Network on Separated Children in Canada, ${ }^{12}$ have formalized this difference by distinguishing "separated" minors from "unaccompanied" minors: separated minors have been separated from both parents, or from their previous legal or customary caregiver, but not necessarily from other adult relatives or friends; unaccompanied minors are separated from both parents and other relatives and are not being cared for by an adult who, by law or custom, is responsible for doing so. ${ }^{13}$ The latter are sometimes referred to as "truly unaccompanied" or "truly separated" in the literature. ${ }^{14}$ It is important to note that minors who are together, whether related or not, but unaccompanied by any adults are considered unaccompanied as long as they are under eighteen.

An interesting aspect of this question on the "acceptable adult" is that there are two ways to determine the veracity of the relationship between that adult and a minor: objective and subjective. Be it biological or legal (e.g. custodial parent or court-appointed guardian), a relationship can be proved by objective documents, such as birth certificates, family registry, or DNA testing. However, this can be particularly challenging to refugees and asylum seekers who often lack documentation and are unable or unwilling to contact the authorities in their country of origin to obtain such documents. Another challenge occurs when a minor is with a family member or other person who may not have formal legal responsibility for the child, but who is a customary caregiver. A second way of establishing an adult-child relationship is by means of a subjective evaluation of the child's physical and psychological state. ${ }^{15}$ Given the possibility of trafficking or abduction of minors, it is essential that both the objective and subjective elements of the relationship be carefully assessed and established.

The literature thus fairly consistently allows for three categories of children, although they are often called by different terms: those who are with a parent or guardian, those who are with non-parental adults, and those who have no adult caregivers. In light of the above analysis, the following terms (see Table 2.1) are used in this paper for our In-Canada Protection Process and our Refugee and Humanitarian Resettlement Program. 
Table 2.1 Definitions of unaccompanied/separated minors used in this paper

\begin{tabular}{|c|c|c|}
\hline Principal Attribute & In-Canada Protection Process & Resettlement Program \\
\hline No acceptable adult present & $\begin{array}{l}\text { Unaccompanied minors refer to individuals } \\
\text { under the age of } 18 \text { for whom no acceptable } \\
\text { adult, neither parents nor others, was present } \\
\text { at the time of asylum claim in Canada. They } \\
\text { are equivalent to resettlement program's } \\
\text { "truly separated minors." }\end{array}$ & $\begin{array}{l}\text { Truly separated minors refer to individuals } \\
\text { under the age of } 18 \text { who are separated from } \\
\text { both parents and are not with and being } \\
\text { cared for by a guardian. They are equivalent } \\
\text { to in-Canada process's "unaccompanied } \\
\text { minors." }\end{array}$ \\
\hline \multirow[t]{2}{*}{$\begin{array}{l}\text { No parent present, but other } \\
\text { acceptable adult(s) present }\end{array}$} & \multirow[t]{2}{*}{$\begin{array}{l}\text { Separated minors refer to individuals under } \\
\text { the age of } 18 \text { who have no parent, but have } \\
\text { other adults, who are willing and able to } \\
\text { provide care, present at the time of asylum } \\
\text { claim in Canada. }\end{array}$} & $\begin{array}{l}\text { Consanguineous minors refer to individuals } \\
\text { under the age of } 18 \text { who are coming to } \\
\text { Canada to be united with a blood relative } \\
\text { (not parents). }\end{array}$ \\
\hline & & $\begin{array}{l}\text { De facto dependents refer to individuals under } \\
\text { the age of } 18 \text { who are emotionally and/or } \\
\text { economically dependent on an adult principal } \\
\text { applicant (PA). The PA may or may not be } \\
\text { their blood relative. De facto dependants } \\
\text { would normally be processed and live with } \\
\text { the PA as members of the same household. }\end{array}$ \\
\hline At least one parent present & $\begin{array}{l}\text { Non-separated minors refer to individuals } \\
\text { under the age of } 18 \text { who had at least one } \\
\text { parent present at the time of asylum claim in } \\
\text { Canada, but for some reason, were coded as } \\
\text { "principal applicant." (See section } 4.2 \text { for the } \\
\text { possible reasons.) }\end{array}$ & N/A \\
\hline
\end{tabular}

\section{Asylum Seeking Minors in Canada}

\subsection{Data and Methods}

The lack of an existing framework for data collection on unaccompanied minor asylum claimants necessitated an original research estimate starting from sample framing/sampling to data collection/analysis. First, we started by defining the population of interest as all claimants who (1) claimed on or between 1 January 2000 and 31 December $2004,(2)$ were under the age of eighteen at the time of claim, (3) were classified as "principal applicants" as opposed to "dependants," and (4) claimed at either Etobicoke, Fort Erie/Niagara Falls, or Toronto Lester B. Pearson International Airport. ${ }^{16}$ The latter restriction was necessary to make on-site review of files manageable. Minor claimant intake at these offices represented a large proportion ( 45.6 per cent) of the national total and did not differ substantially from the latter. ${ }^{17}$ Citizenship and Immigration Canada's administrative database, called Field Operational Support System (FOSS), identified 3,021 such individuals, i.e., recent claimants under age eighteen identified as principal applicants at a major airport, land border, or inland immigration office in Ontario. ${ }^{18}$

Second, from this sampling frame, a highly representative sample of 280 claimants (approximately 10 per cent) was randomly selected using the software program SPSS. (See the Appendix for a table illustrating how representative the final random sample is compared to the national claimant population and the sampling frame.) Third, a template listing all relevant information was developed and a team of researchers completed it for each of the 280 claimants by physically reviewing some files deposited in the Toronto and Niagara Falls areas and conducting individualized in-depth searches of electronic immigration databases. ${ }^{19}$ No attempt was made to match every record in every database; in general, a case would be followed through as many databases as necessary to determine the presence and identity of adults around the time of the claim. The electronic file in the main immigration database, FOSS, or the paper file often identified the presence of parents, other adults, and siblings. For example, the record of a court case would indicate that it was 
brought by someone else on behalf of the child. Further matches were made by checking other immigration databases, in which the child might have been reunited with other family members after the claim was made. The following sections show findings from this custom-built database.

\subsection{Who Are the Unaccompanied Minor Asylum Claimants?}

For the purpose of this study, all findings are reported for three subgroups. The first group, unaccompanied minors, consists of those for whom no adult - neither parents nor any other acceptable adults - was present when they claimed. As Table 3.1 shows, among the 280 children in the sample, there were forty-six unaccompanied minors. In detail, thirty-four of forty-six were completely alone while twelve claimed with other minors, such as their siblings/relatives or friends. Minors for whom smugglers were the sole present adult are included in this group, too (more on smugglers later). In total, unaccompanied minors, who represent potentially the most vulnerable group, composed only 16.4 per cent of the total sample. The second group, separated minors, consists of those who had no parent present, but had other adults present around claim time. These adults ranged from relatives (e.g. grandparents, stepparents, adult siblings, aunts, uncles, spouse, and cousins) to friends and family friends. Separated minors represented 25.4 per cent. Finally, non-separated minors were those accompanied by at least one parent, but were coded as "principal applicants." 20 Among the 163 non-separated minors, seventy-six had both parents present around claim time, sseventy-one had their mother but not father, and sixteen had their father but not mother. In all 163 cases, other minors and/or adults might also have been present. In total, this non-separated minors group was by far the largest (58.2 per cent).

How could these proportions be used to estimate the number of unaccompanied minors nationally? According to administrative databases, there were a total of 172,516 adult and minor claimants in 2000-2004. Among them, 6,627 were principal applicants under the age of eighteen. (Of these, 3,021 claimed in the three areas that formed the basis of our sample.) As a starting point for further investigation, if the percentages in Table 3.1 are nationally representative, estimates would indicate that 1,087 unaccompanied minors (16.4 per cent of 6,627), 1,683 separated minors (25.4 per cent) and 3,857 non-separated minors (58.2 per cent) claimed in 2000-2004.

In the single year of 2000 , there were 1,218 principal applicants under the age of eighteen. Applying the same technique, our estimates would result in 200 unaccompanied minor claimants (16.4 per cent of 1,218), 309 separated minor claimants (25.4 per cent) and 709 non-separated minor claimants ( 58.2 per cent) for 2000 . Therefore, the widely used figure of " 1,088 unaccompanied minor claimants in 2000 " 21 seems to reflect the total number of principal applicants under the age of eighteen, not the number of truly unaccompanied minors as in our definition.

These figures also suggest that Canada may be receiving relatively fewer unaccompanied minors than other countries. The UNHCR estimates the number of unaccompanied minors to be 2 per cent to 5 per cent of the international refugee population. ${ }^{22}$ According to our analysis, unaccompanied minors represented only 0.63 per cent of the total claimant population (1,087 out of 172,516). Even the sum of unaccompanied and separated minors would only amount to 1.61 per cent of total claimants.

Table 3.1. Socio-demographic characteristics: group size, gender, age at claim and top three countries of alleged persecution

\begin{tabular}{||l|c|c|c|l||}
\hline & N (Col. \%) & Female (Row\%) & Mean age & \multicolumn{1}{|c||}{ Top three countries } \\
\hline Unaccompanied & $46(16.4 \%)$ & $18(39.1 \%)$ & 15.2 & Sri Lanka, China, Burundi \\
\hline Separated & $71(25.4 \%)$ & $36(50.7 \%)$ & 15.3 & Sri Lanka, Somalia, Colombia \\
\hline Non-separated & $163(58.2 \%)$ & $78(49.9 \%)$ & 10.0 & Pakistan, Sri Lanka, Costa Rica \\
\hline Total Minors & $280(100.0 \%)$ & $132(47.1 \%)$ & 12.2 & Sri Lanka, Pakistan, Somalia \\
\hline
\end{tabular}


In terms of gender distribution, separated and non-separated minors showed highly balanced gender ratios. On the other hand, unaccompanied minors showed higher representation of males compared to females, as only 39.1 per cent were female. ${ }^{23} \mathrm{~A}$ Quebec-based study ${ }^{24}$ also found that boys and young men were overrepresented among unaccompanied minors. In fact, despite the fact that women and children make up the vast majority of world's refugee population, men continue to constitute the majority of those claiming asylum in Western nations. This is partly because women and children often lack the necessary resources and skills to make their way to Canada or other Western asylum countries and claim asylum.

Regarding age at claim, unaccompanied minors and separated minors showed a comparable mean age of 15.2 and 15.3 years respectively while non-separated children showed a much younger mean age of ten years. This is understandable since very young children are less likely to be away from their parents. In fact, the youngest unaccompanied minor was seven years old and almost half of them were seventeen years old. The pattern was similar for the separated minors. In contrast, thirty-nine (or 23.9 per cent) of non-separated minors were aged five or under (figures not shown).

Where do they come from? The top countries of alleged persecution reported by all adult and minor claimants in 2000-2004 were Pakistan, Colombia, Republic of China, Mexico, and Sri Lanka, in descending numerical importance. Minor claimants shared most of these countries, as shown in other studies, ${ }^{25}$ except for Burundi, Somalia, and Costa Rica. Costa Rica ranked eighth among the overall claimants, but neither Burundi nor Somalia figured among the top ten countries for overall claimants. However, the numbers are too small to yield a firm conclusion about distinct patterns of minor migration.

\subsection{How Are They Received?}

In terms of the in-Canada refugee determination processes, minor claimants, especially the unaccompanied and separated minors, differed somewhat from the overall claimant population. Starting with eligibility assessment at the front end of the determination process, compared to over 99 per cent of total claimants who were eligible in 2000-2004, a slightly lower proportion of 93.6 per cent of minors were eligible (Table 3.2). It is unclear why separated minors would show a higher proportion of eligibility than unaccompanied and non-separated children. However, it is fair to state that a large majority of minors were eligible. For all subgroups, the primary reason for ineligibility was not completing the eligibility screening process (prior to June 2002) or having made a previous claim in Canada (after June 2002).

Once eligibility is established, claimants are referred to the IRB for individual hearings. Our figures show that unaccompanied and separated minors who claimed in 2000-2004 had substantially higher acceptance rates (61.0 per cent and 57.1 per cent respectively) than the overall claimant population, for whom only 44.1 per cent of finalized decisions made in 2000-2004 were positive. Non-separated minors differed, as they showed a slightly lower rate than the overall claimants at 40.4 per cent. Although no direct comparisons can be made, as the available data is from various time frames, is based on various definitions of "unaccompanied," and includes cases coming from various countries, a preliminary conclusion is that the figure of " 50 per cent acceptance rate in $2000 " 27$ seems to match the total minor figure (48.1 per cent), and not that of the subgroup of unaccompanied minors. Therefore, our figures do not confirm the American data presented by Bhabha ${ }^{28}$ that "separated children have a lower success rate in asylum claims than accompanied children or adults." ${ }^{29}$ We found no other comparable

Table 3.2. Minors in the In-Canada Refugee Determination Process

\begin{tabular}{|l|c|c|c||}
\hline & Eligible & $\begin{array}{c}\text { Positive IRB } \\
\text { Decision }\end{array}$ & $\begin{array}{c}\text { Average time from } \\
\text { claim to IRB decision }\end{array}$ \\
\cline { 2 - 4 } & $41(89.1 \%)$ & $25(61.0 \%)$ & 392 days \\
\hline Unaccompanied & $70(98.6 \%)$ & $40(57.1 \%)$ & 379 days \\
\hline Noparated & $151(92.6 \%)$ & $61(40.4 \%)$ & 476 days \\
\hline Total Minors & $262(93.6 \%)$ & $126(48.1 \%)$ & 438 days \\
\hline
\end{tabular}


publication containing acceptance rates of unaccompanied or separated minors in Canada.

It is also interesting to note that, on average, it took non-separated minors approximately one hundred more days to have their cases heard at the IRB than their unaccompanied or separated peers. This may be because the IRB Chairperson's Guidelines related to procedure for child refugee claimants suggest that their claims be given scheduling and processing priority, as it is generally in the best interests of the child to have the claim processed as expeditiously as possible.

\subsection{Relationship with Adults and Special Needs}

No one disputes that children, by virtue of being children, need immediate and comprehensive assistance, not only for the refugee determination process, but for all other aspects of their lives. ${ }^{30}$ They need assistance with food and shelter, medical care, and education, and, in general, adult guidance in their daily lives and protection from those who might harm or exploit them. They may also require specialized emotional support, due to their situation of separation, and specialized legal assistance.

For some minors, their contact with adults in the immigration process involves smugglers, often referred to as "agents," "snakeheads," or "coyotes." Out of 280 children in our sample, forty-seven files recorded the presence of smugglers either during the travel or around the claim time. ${ }^{31}$ Understandably, the proportion reporting the presence of smugglers was higher among the unaccompanied and separated minors (28.3 per cent and 38.0 per cent respectively) than among the non-separated minors (16.8 per cent). Although the small sample size prevents a firm conclusion, interesting patterns by country of alleged persecution emerged: among the few countries that had more than ten minors, those coming from Somalia (9/17), Nigeria $(6 / 12)$ and Sri Lanka (12/31) were much more likely to report smugglers than China (3/16), Pakistan (1/17), Mexico (0/12), Costa Rica (0/12), and Colombia (0/16).

When a child arrives in Canada with parents, the parents are responsible for the physical and emotional well-being of the child, including whatever support is needed to deal with the system, while the Immigration Officer is responsible for the immigration process. When the child is unaccompanied or separated, however, the immigration officer, while still primarily dealing with the immigration process, may have obligations under child welfare legislation and personal ethics pertaining to the child's safety. ${ }^{32}$ This responsibility may lead to contact with the relevant child welfare authorities, NGOs, designated representatives, or legal counsel. ${ }^{33}$ Like other issues under IRPA, the choice of whether to formally report a child to the child welfare authorities must be made on a case-by-case basis. The officer must exercise judgment as the possibility of risk to an unaccompanied child will depend on many circumstances, including the child's age and the appropriateness of any arrangements previously made for the child's care. "Risk," in the child welfare context, does not refer to risk of persecution, but rather to risk as defined under the child welfare legislation in the province in which the claim is made.

\subsection{Summary and Conclusion}

What do these analyses show? First of all, as Montgomery, Rousseau, and Shermarke ${ }^{34}$ rightly state, "unaccompanied minors," however defined, constitute a highly heterogeneous population. They exhibit a wide spectrum of sociodemographic characteristics, come from many different countries and backgrounds, face a variety of conditions upon their arrival, and possess various needs of protection.

Second, detailed file review showed that the number of unaccompanied and separated minor claimants in Canada may be much smaller than previously reported. Previous researches have been based on quantitative data from existing administrative databases, which we found to be inadequate at accurately identifying the population of interest.

Third, unaccompanied and separated minor claimants showed distinct patterns compared to non-separated minors and adult claimants. Unaccompanied and separated minors were older than non-separated minors. Compared to non-separated minors and adult claimants, unaccompanied and separated minors were likely to come from different countries, more likely to have connection with smugglers, and slightly less likely to be eligible, but more likely to obtain a positive decision at the IRB once referred. They usually took a shorter time to obtain their decision, and were more likely to have help from professional childcare personnel. These differences re-emphasize the need to distinguish non-separated minors from unaccompanied and separated minors in future research.

\section{Resettled Minors in Canada}

\subsection{Data and Methods}

As stated above, administrative databases at Citizenship and Immigration Canada are not designed to capture which and how many minors were truly separated. This is as true for resettled minors as it is for asylum-seeking ones. In the resettlement context, the database does not currently capture how many minors arrived in Canada as consanguineous minors or how many were resettled as de facto dependants. However, it should be noted that the sample used in the resettled minors section differs from that used for asylum seeking minors above. 
While we looked generally at all resettled individuals under the age of eighteen who are classified as principal applicants (heads of households), a small-scale individual review of all 294 CAIPS files of minors resettled as principal applicants in 2003 and 2004 was also conducted to identify the size and basic details of these subgroups. ${ }^{35}$ Findings from this file review are reported below, but the majority of the resettlement section is based on all resettled individuals under the age of eighteen. All individuals in this aspect of our study under the age of eighteen are generically referred to as "separated minors."

\subsection{Who Are the Resettled Minors?}

Figure 4.1 below provides a snapshot of the number of principal applicants under the age of eighteen who have been resettled to Canada between 1995 and 2004 as Government Assisted Refugees (GARs) or Privately Sponsored Refugees (PSRs). Figure 4.1 shows a significant increase in resettled separated minors since 2000. However, the increases likely represent a new record-keeping procedure and the introduction of a more humanitarian interpretation of family rather than an actual increase in the number of separated minors resettled in Canada.

Figure 4.1

Number of Government Assisted and Privately Sponsored Minor Refugees, 1995-2004

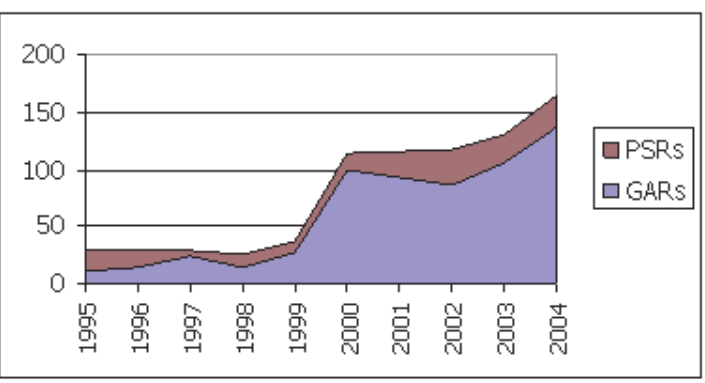

Between 1995 and 1999, visa officers tended to process children who were not biological offspring under a non-parental principal applicant head of household. ${ }^{36}$ In other words, de facto dependants were processed as true dependants and are excluded from the 1995-1999 figures. The practice stopped in 2000, so the number shown in Figure 4.1 between the years 1995 and 1999 is likely to include primarily truly separated and consanguineous minors. The next marginal increases in GARs in 2003 and 2004 are likely a result of the introduction of the Immigration and Refugee Protection Act (IRPA) in 2002; more specifically, of the changes making the Refugee and Humanitarian Resettlement program more accessible to those most in need. It is interesting to note that, since the moratorium on resettling truly separated minors was introduced in May 2001, the number of principal applicants under eighteen between 2002 and 2004 was therefore more likely to be comprised mostly of de facto dependants and consanguineous minors and not truly separated minors.

In order to provide some clues to the distribution of these three subgroups of minors (consanguineous, de facto and truly separated), the files of all of the resettled principal applicant minors for the years 2003 and 2004 were examined. Table 4.1 presents the breakdown. As expected with the moratorium, very few truly separated minors were resettled in 2003-2004. Between consanguineous minors and de facto dependants, the latter was much larger, at 70.4 per cent of the total principal applicants under eighteen. The file review ${ }^{37}$ has revealed that the majority of separated

Table 4.1. Detailed file review: Distribution of consanguineous, de facto and truly separated minors, 2003-2004

\begin{tabular}{||l|c|c||}
\hline & Total (Col.\%) & Female N (\%) \\
\hline Truly separated & $2(0.7 \%)$ & $2(100.0 \%)$ \\
\hline Consanguineous & $59(20.1 \%)$ & $21(35.6 \%)$ \\
\hline De facto & $207(70.4 \%)$ & $93(44.9 \%)$ \\
\hline Unknown & $26(8.8 \%)$ & $11(42.3 \%)$ \\
\hline Total & $294(100.0 \%)$ & $127(43.2 \%)$ \\
\hline \hline
\end{tabular}

minors were de facto minors. The majority of these de facto minors travelled with an adult, usually an aunt or an uncle. However, interestingly, based on the information collected at the time of the file review, the majority of de facto dependants under the age of twelve were travelling with their older single siblings rather than an adult with other dependant family members (such as an uncle with his own biological children). This data therefore seems to indicate that in the absence of parents, older single siblings are more likely to take on the care of their younger siblings than an older sibling with dependants of his/her own. ${ }^{38}$ Many of those who fell into the consanguineous category were joining an aunt or an uncle in Canada.

Moving from this smaller file review back to the overall resettled minor population, Table 4.2 shows their sociodemographic traits. Regarding gender, Table 4.2 shows that 40.9 per cent of resettled minors resettled in 2000-2004 
were females. Compared to the overall resettled population (adults and minors) in the same period, where 47.9 per cent were females, female minors seem under-represented. This is despite some of the program reforms of 2000 and 2002 which aimed at ensuring more equitable access to Canada's resettlement program by women and children who make up the vast majority of the world's refugees. ${ }^{39}$

Table 4.2.

Gender and source country of resettled minors, 2000-2004

\begin{tabular}{||l|c|l|l||}
\hline \hline & Total & Female N (\%) & \multicolumn{1}{|c|}{ Top Countries } \\
\hline \hline 2000 & 114 & $49(43.0 \%)$ & $\begin{array}{l}\text { Sudan, Yugoslavia, } \\
\text { Burundi }\end{array}$ \\
\hline 2001 & 116 & $46(39.7 \%)$ & Sudan, Congo, Ethiopia \\
\hline 2002 & 117 & $40(34.2 \%)$ & $\begin{array}{l}\text { Sudan, Ethiopia, } \\
\text { Burundi }\end{array}$ \\
\hline 2003 & 130 & $51(39.2 \%)$ & Sudan, Congo, Ethiopia \\
\hline 2004 & 164 & $76(46.3 \%)$ & Sudan, Congo, Somalia \\
\hline \hline Total & 641 & $262(40.9 \%)$ & Sudan, Congo, Burundi \\
\hline
\end{tabular}

In terms of source countries, resettled minors of 2000-2004 do bear resemblance to the general resettlement population in that most came from Africa. While most refugees resettled to Canada came from Eastern Europe and Asia prior to 2000, the Middle East and African countries represent over 50 per cent of all resettled refugees to Canada today. However, in terms of individual countries, minors show slightly different source countries than the overall resettled population. The top eight source countries for the overall resettled population in 2000-2003 were Afghanistan, Yugoslavia, Colombia, Sudan, Iraq, Iran, Ethiopia, and Bosnia-Hercegovina. In comparison, in addition to Sudan and Ethiopia, resettled separated minors came from Congo, Burundi, and Somalia. For some reason, family units in Afghanistan, Yugoslavia, and Colombia seem either to have remained more intact or to have more mothers who have been able to continue as the head of family when compared to families in Africa. It may be that the prevalence of conditions outside the refugee situation, such as HIV/AIDS, may have rendered more children without either parent in Africa.
It is important to note the implication of this difference. In addition to the fact that refugee children, especially separated children, are among the most vulnerable children in the world, those coming from African countries are even more vulnerable than those resettled in the past from European countries. Young children from the top countries shown in Table 4.2 are likely to have witnessed or have been the victims of atrocities such as bombings, militia attacks, child soldier recruitment, burning of entire villages, rapes, and executions of civilians. Further, young girls are at higher risk of being forced to work as child prostitutes for rebel armies in order to support themselves and, in some cases, their families. ${ }^{40}$ Therefore, it should be noted that, in addition to the fact that post-IRPA resettled refugees may have higher needs generally, it is likely that the resettled separated minors may have even higher psychosocial needs.

\subsection{How Are Resettled Minors Received?}

All resettled refugees receive resettlement assistance but the amount and type that they receive is dependant upon their level of need relative to the other refugees being resettled. GARs receive up to twelve months of income support through the Resettlement Assistance Program (RAP) while PSRs receive similar assistance but have the added support of a volunteer for up to one year to help with the day-to-day challenges of adjusting to life in Canada. However, it is important to note that all assistance for resettled refugees is first and foremost designed to assist the adult principal applicant or head of household take care of his/her dependants and settle into Canadian society. Furthermore, integration programs and services are designed to directly address the needs of an adult caregiver rather than a minor. The adult is expected to look out for the needs of the minors and as such the programs will also include guidance on how to care for minors within Canadian society. It should be noted that the infrastructure is not in place to address the needs of minors directly nor are existing programs equipped to provide the care and attention necessary to protect minors arriving in Canada for the first time without an adult caregiver.

As noted above, provincial and territorial governments have jurisdiction in matters of child protection and social services; each province has its own child protection, child welfare, and guardianship legislation, and the care provided to separated children varies from one province to another. As a general rule, there is no requirement to involve provincial child welfare services when destining resettlement cases with a de facto or consanguineous minor given that these minors are in the care of an adult guardian. ${ }^{41}$ As with any other permanent resident or Canadian citizen family, provincial services do not interfere in private families unless 
there is reason to believe that the minor is in need of protection from the adult caregiver or unless the adult caregiver is unable to ensure the safety of the child. ${ }^{42}$ However, the responsibilities of CIC and the provinces overlap in the resettlement of separated minors. Therefore, in all cases involving truly separated minors, $\mathrm{CIC}$ is required to consult with the ministry responsible for child welfare in the anticipated province of destination before making a decision to accept the minor.

Concerns surface where the adult caregiver abandons the de facto or consanguineous minor before the minor has reached the age of majority in the province in which they have been settled. When this happens within the first year of their arrival in Canada, this poses many complications for CIC, the province, and the minor since the minor may not be able to access the necessary supports. In provinces where the age of protection extends to include eighteen, resettled refugee minors who are abandoned by their guardian may seek the necessary protection services from the provincial government to ensure they are cared for until they reach the age of majority when they can work and obtain the benefits of an adult. In provinces where the age of protection extends only to fifteen, the abandoned minor may be placed in very real danger. This is due to the fact that the minor will still be relatively unfamiliar with Canadian society and, therefore, may very well lack a social support network.

\subsection{Future Policy Development}

CIC is working towards a national resettlement policy to prevent, as much as possible, resettled children from becoming victims of abuse and exploitation once here in Canada.

In recent years, CIC has engaged in consultation with provincial governments, NGOs, and the UNHCR to explore the issues associated with resettling separated minors. The first measure resulting from these consultations was the moratorium, in 2001, on separated minors without an adult guardian to care for them. The moratorium is expected to continue until we have an infrastructure in place to welcome and receive separated minor refugee children in a way that can ensure their physical protection and safety, including their financial independence until they reach the age of majority.

The second step was addressing the importance of ensuring children resettled to Canada are part of bona fide familial relationships. To that end, CIC with provinces, child welfare authorities, and the UNHCR has developed a national "guardianship protocol." In an attempt to mitigate the circumstances that give rise to family breakdown and exploitation, CIC is dealing with procedural issues to ensure refugee minors are brought into, or are part of, bona fide familial relationships that can provide the necessary safety and protection of the minor until the minor reaches the age of majority in the province in which they reside. The guardianship protocol, in the final stages of development, will also amend the definition of separated minors to: "an individual under the age of eighteen without the care and protection of a legal guardian."

The guardianship protocol will ensure every adult bringing a child into Canada as a de facto dependant or as a consanguineous minor understands their obligations as the adult caregiver. It will also facilitate the acquisition of legal guardianship for these children. To further help persons apply for legal guardianship, CIC has amended the terms and conditions for federal resettlement assistance so that $\mathrm{CIC}$ is able to cover the administrative costs associated with legalizing guardianship.

CIC also expects to further engage partners and stakeholders to develop the infrastructure necessary to allow Canada to resettle and ensure adequate care and protection of separated minors. In anticipation of such a development, CIC included in its April 2005 amendments to the Resettlement Assistance Program the flexibility to cover expenses unique to separated minors not normally considered integration expenses. In addition, new guidelines have been approved to use a secondary source of the resettlement assistance budget known as RAP "B" funding. For separated minors, this means the capacity exists to fund special programming initiatives or orientation sessions designed specifically to address the settlement needs of separated minors who arrive in Canada without an adult guardian. While there are no immediate plans for this type of programming, RAP " $\mathrm{B}$ " funding is expected to contribute to the development of a solid Canadian infrastructure that supports the care and protection of separated minors in the future.

CIC is committed to ensuring the protection of resettled refugee minors. The policy decisions taken in 2000 and again in 2002 were the first steps in that regard, both in terms of the relaxed settlement criteria and the record keeping policies. However, there is still much work to be done.

\section{Conclusion}

Scholars and NGOs have for long expressed concerns about the lack of reliable data and policy framework concerning the particularly vulnerable group of unaccompanied minor refugees in Canada: How many unaccompanied minor refugees are there? Who are they? How are they received? Using existing administrative databases to the fullest extent, this paper has sought to fill some of the information gaps.

Concerning their number, detailed file review has shown that truly unaccompanied minors were many fewer than 
previously reported. In the asylum stream, extrapolating from a sample suggests that only 0.63 per cent $($ or 1,087$)$ of the total claimant population had claimed unaccompanied by adults in the past five years. Even when those accompanied by non-parental adults are added, the figure only amounts to 1.61 per cent or 2,770 in 2000-2004. In the resettlement stream, partly due to the moratorium, only two truly unaccompanied minors were resettled in 2003-2004 (Table 4.1). Compared to other countries, especially to some European countries where the phenomenon of unaccompanied minors is much more prevalent, these figures are very small.

Who are they? On this, our data agree with previous findings that unaccompanied minors compose a highly heterogeneous and vulnerable group. They come from many different countries, often the same countries as the adult refugee population, but sometimes not. They tend to be older than accompanied minors. Unaccompanied or separated asylum minors are more likely to be males, but the two separated resettled minors were females.

About how they are received and what their specific needs are, very little evidence exists. Our study found that unaccompanied and separated asylum-seeking minors showed a higher acceptance rate and quicker processing times than the adult population, but details about their actual reception into Canada remains to be further explored.

What can be done to address the needs of this particularly vulnerable group of refugees? As a first step, Citizenship and Immigration Canada (CIC) needs to institutionalize a way of improving data entry quality which will allow the distinction of different subgroups of minor refugees. Currently, neither the asylum nor the resettlement database is able to accurately identify the different subgroups of separated/unaccompanied minors: in the case of asylum-seeking minors, those presenting themselves with no adult (unaccompanied) are not distinguishable from those who come with non-parental adults (separated) or even from those who come with a parent (non-separated). On the resettlement side, those coming completely by themselves (separated) are not distinguishable from those joining their non-parental blood relatives (consanguineous) or those being processed with guardians (de facto dependants). Unfortunately, previous research has been based on these aggregated figures. Once these subgroups become identifiable through a better data collection method and awareness at CIC, all existing data (e.g. gender, age, countries of origin, and much more) could be used to a much fuller extent. In concrete terms, a set of operational guidelines towards this end must be developed. These would review the input criteria for current administrative databases and ensure the necessary fields are available in the database which is being implemented.

When systems are in place to accurately identify separated and unaccompanied minors on a long-term basis, we will be able to develop a research-based policy framework to address the specific needs of this group. Although they are small in number, they are a particularly vulnerable population, subject to such abuses as trafficking in persons and lack of physical and emotional support. It is hoped that the attempt at defining the subgroups as well as some preliminary analysis into their numbers and reception that is presented in this paper will constitute the first step towards such policy framework. 


\section{Appendix}

The following table illustrates how representative the final random sample is compared to the national claimant population and the sampling frame.

\begin{tabular}{|c|c|c|c|}
\hline & $\begin{array}{c}\text { National Minor } \\
\text { Claimant Population }\end{array}$ & $\begin{array}{l}\text { Sampling Frame } \\
\text { (3 offices) }\end{array}$ & $\begin{array}{c}\text { Final } \\
\text { Random Sample }\end{array}$ \\
\hline Mean age (years) & 11.84 & 12.18 & 12.67 \\
\hline Male & $3,588(54.1 \%)$ & $1,634(54.1 \%)$ & $148(52.9 \%)$ \\
\hline Female & $3,039(45.9 \%)$ & $1,387(45.9 \%)$ & $132(47.1 \%)$ \\
\hline Etobicoke & $1,692(25.5 \%)$ & $1,692(56.0 \%)$ & $160(57.1 \%)$ \\
\hline Fort Erie/Niagara Falls & $927(14.0 \%)$ & $927(30.7 \%)$ & $85(30.4 \%)$ \\
\hline Pearson International & $402(6.1 \%)$ & $402(13.3 \%)$ & $35(12.5 \%)$ \\
\hline Not selected & $3,606(54.4 \%)$ & N/A & N/A \\
\hline Total N & 6,627 & 3,021 & 280 \\
\hline
\end{tabular}

\section{Notes}

1. Mehrunnisa A. Ali, Svitlana Taraban, and Jagjeet Kuar Gill, "Unaccompanied/Separated Children Seeking Refugee Status in Ontario: A Review of Documented Policies and Practices" (working paper no. 27, CERIS Working Paper Series, Joint Centre of Excellence for Research on Immigration and Settlement, Toronto, August 2003), http://ceris.metropolis.net/Virtual\%20Library/Demographics/CWP27_Ali.pdf (accessed 2 November 2005); Judith Kumin and Danya Chaikel, "Taking the Agenda Forward: The Roundtable on Separated Children Seeking Asylum in Canada," Refuge 20 (2002): 73-77.

2. Review of Canada's Second Report by the UN Committee on the Rights of the Child, 17 September 2003, para. 96, <http:// www.pch.gc.ca/progs/pdp-hrp/docs/crc_e.cfm> (accessed 2 November 2005).

3. Provincial and territorial governments have jurisdiction in matters of child protection and social services while the federal government retains power over the selection of all immigrants to Canada.

4. Immigration and Refugee Protection Act [IRPA], S.C. 2001, c. 27; Immigration and Refugee Protection Regulations, SOR/2002-227; Regulations Amending the Immigration and
Refugee Protection Regulations, Canada Gazette 138, no. 22, 3 November 2004, <http://www.cic.gc.ca>.

5. Convention relating to the Status of Refugees, 28 July 1951 (entered into force 22 April 1954, accession by Canada 2 September 1969) [Refugee Convention], <http://www.unhchr. $\mathrm{ch} / \mathrm{html} / \mathrm{menu} 3 / \mathrm{b} /$ o_c_ref.htm $>$ (accessed 2 November 2005); Protocol Relating to the Status of Refugees, 1967 (entered into force 4 October 1967, accession by Canada 4 June 1969), <http://www.unhchr.ch/html/ menu3/b/o_p_ref.htm> (accessed 2 November 2005).

6. Convention on the Rights of the Child, 1989 (entered into force 2 September 1990, ratified by Canada 13 December 1991); Can T.S. 1992 No. 3.

7. Humanitarian and Compassionate Consideration, IRPA, supra note 4 at section 25 .

8. Under the previous Immigration Act, an equal consideration was given to the individual's ability to establish, and to his or her need for protection. As a result, principal applicants were discouraged from taking responsibility for dependants who did not meet the definition of dependent family members, such as nieces and nephews, including children. As minors without biological parents or legal guardians were considered 
in their own right, it was very rare that unaccompanied minors were able to demonstrate their ability to establish.

9. There is a moratorium against the resettlement of all truly separated minors, except where the UNHCR determines resettlement to Canada to be the most appropriate solution and where CIC is able to ensure with provinces, the adequate care and protection of the minor. These situations are dealt with on a case-by-case basis.

10. Jan Williamson and Audrey Moser, Unaccompanied Children in Emergencies: A Field Guide for Their Care and Protection (International Social Service, 1989), 37. The authors use the terms separation with (abandoned, entrusted, living independently) or without (lost, orphaned, run away, abducted) the parents' consent.

11. For example, a child claimant whose parents are already permanent residents may be considered unaccompanied for the purpose of his/her referral to the IRB because his/her parents do not have open refugee claims. For the purpose of our study, however, she or he will be categorized as a non-separated asylum minor.

12. International Bureau for Children's Rights (IBCR), Best Practices Statement on Separated Children in Canada (Montreal: IBCR, 2002), <http://www.ibcr.org > (accessed 2 November 2005).

13. The Committee on the Rights of the Child includes, without comment, both definitions in General Comment No. 6 (2005) entitled "Treatment of unaccompanied and separated children outside their country of origin." The UNHCR's Refugee Children: Guidelines on Protection and Care (Geneva: 1994) contains two checkboxes, for "unaccompanied" and "separated" children.

14. There are other definitions of acceptable adults, as well. Regulation 228(4) under the IRPA (supra note 4), which stipulates an exemption for the Minister when making a removal order, applies to a minor "not accompanied by a parent or an adult legally responsible for them.” Safe Third Country Regulations (supra note 4) define the exception for "an unaccompanied minor" as "not accompanied by their mother, father or legal guardian, has neither a spouse, nor common-law partner and has neither a mother or father nor a legal guardian in Canada or the United States." The Immigration and Refugee Board Chairperson's Guidelines, issued under IRPA, define these adults as persons who purport to be members of the child's family if the IRB is satisfied that these persons are related to the child. Immigration and Refugee Board, Guideline 3, Child Refugee Claimants: Procedural and Evidentiary Issues (Ottawa: Guidelines Issued by the Chairperson, 1996), <http://www. irb-cisr.gc.ca>.

15. UNHCR's 1997 Guidelines on Policies and Procedures in Dealing with Unaccompanied Children (Geneva: 1997) (Annex II, Point 5) point out that where a child is accompanied by an adult caregiver, the quality and durability of the relationship between the child and the caregiver must be evaluated to decide whether the presumption of "unaccompanied status" should be set aside. .
16. "Etobicoke" includes Etobicoke Canada Immigration Centre, Greater Toronto Area West Management area; "Fort Erie/Niagara Falls" includes Ft. Erie Peace Bridge, Niagara Falls Whirlpool Bridge, Niagara Falls Rainbow Bridge, Niagara Falls Queenston-Lewiston Bridge, Niagara Falls Selection, Integration and Refugee Operations, and Niagara Falls Enforcement; "Toronto Lester B. Pearson International Airport" includes Terminals 1, 2, and 3 and Operations.

17. See the Appendix for comparison.

18. The 3,021 minor claimants from the three offices constituted almost half of total national minor claimants in the same period $(45.6 \% ; \mathrm{N}=6,627)$.

19. Primarily Field Operating Support System (FOSS), with help from National Case Management System (NCMS), Computer Assisted Immigration Processing System (CAIPS) and Case Processing Center database (CPC).

20. There are a number of reasons why non-separated minors (accompanied by at least one parent) would be coded as principal applicants in the administrative database. For example, the parents may be permanent residents or citizens of Canada, making the minor the only and principal claimant. Alternatively, parents may have claimed at different times than the child or against a different country of persecution. It could also be due to coding errors. Due to a computer coding error, some offices for some period of time were instructed to code all claimants as principal applicants.

21. Wendy Ayotte, Separated Children Seeking Asylum in Canada: A discussion paper adapted from an original report researched and written by Wendy Ayotte (Ottawa: UNHCR Branch Office for Canada, 2001), 8, (http://www.web.net/ ccr/separated.PDF).

22. Catherine Montgomery, "The Brown Paper Syndrome: Unaccompanied Minors and Questions of Status," Refuge 20 (2002): 57.

23. For the same period of 2000-2004, 41.6 per cent of all claimants (both minors and adults) were female.

24. Catherine Montgomery, Cecile Rousseau, and Marian Shermarke, "Alone in a Strange Land: Unaccompanied Minors and Issues of Protection," Canadian Ethnic Studies 33 (2001): 105.

25. Kumin and Chaikel, supra note 1 at 5.

26. Out of 280, 18 were not referred (ineligible) to the IRB and 7 were still waiting to be scheduled at the time of the survey. These cases were excluded from the time calculation.

27. Supra note 19 at 10.

28. Kumin and Chaikel, supra note 1 at 75.

29. Similarly, the IRB's statistics also show a higher acceptance rates for separated minors (by their definition) than others: while the overall acceptance rate between July 2004 and May 2005 was 40 per cent, that of "separated children" in Ontario was 51 per cent; (personal communication).

30. Geraldine Sadoway, "Canada's Treatment of Separated Refugee Children," European Journal of Migration and Law 3 (2001): $347-81$ at 352 . 
31. While the relationship of the child with a smuggler ends before or on arrival, some smugglers may also be traffickers who will continue to exploit the child in Canada.

32. Citizenship and Immigration Canada, "Protected Persons 1 , Processing Claims for Protection in Canada, chapter 14, Procedure - Minor Children," in Immigration and Refugee Protection Act Manual, <http://www.cic.gc.ca/manuals-guides/ english/pp/index.html $>$. The manual states, for example, that "For the purpose of reception, whether the person accompanying them (or coming to meet them) is able to provide sufficient care, should be referred to provincial authorities as appropriate." Under the IRB Chairperson's Guidelines, claims of unaccompanied children should be identified as soon as possible by the IRB registry staff. The name of the child and any other relevant information should be referred to the provincial authorities responsible for child protection issues, if this has not already been done by Citizenship and Immigration Canada (CIC). The Guidelines state that an unaccompanied child claimant is by virtue of that status a child who may be at risk and the authority responsible for children at risk should be notified.

33. IRPA requires the IRB to designate a representative for every person under eighteen. CIC has no authority to designate a representative, but it is preferred that every child have an appropriate adult to assist with the claim in its early stages before it goes to the Board. This adult should act in the best interests of the child and not be in a conflict of interest position with the child. It may be someone who has travelled with, or come to meet, the child, or someone asked to assist according to regional/office practice.

34. Montgomery, Rousseau, and Shermarke, supra note 24 at 106.

35. CAIPS is one of CIC's databases and is the main system used in missions overseas to record case notes for refugee selected for resettlement.

36. This may be because the officers recognized that circumstances, such as separation from family members as a consequence of civil war or death of parents/guardians, often force minors to become de facto members of other families. Also, some refugee families may actively select a child to join their extended family/community/tribe members in displacement.

37. CAIPS,

38. Section 141 of IRPA; OP 5 One-year window of opportunity (OYW), section 6.34.

39. De facto dependency may vary on the basis of gender, as boys are more likely to be able to live in large groups as minors and separated girls are frequently "adopted" into families within their extended family and/or ethnic group. For girls who become de facto members of another family, it may mean that they are treated as a de facto "child," but it can also mean that they become victims of gender-based violence.

40. See "Refugee Children in Southern Africa Share Their Perception of Violence," Africa Newsletter, UNHCR Africa Bureau, August 2005; and "Note for Implementing and Operational Partners on Sexual Violence and Exploitation: The Experience of Refugee Children in Guinea, Liberia, and Sierra Leone,” UNHCR, February 2002.

41. Both government-sponsored and privately sponsored refugees are not entitled to social assistance during the period of the sponsorship. The financial sponsorship period is normally one year but may be extended to two years in some cases of government-assisted refugees and three years in special private sponsorship cases.

42. Each province has legislation which defines the nature of child protection.

Judith Wouk has recently retired from her position as Senior Policy Advisor in the Refugees Branch of Citizenship and Immigration Canada.

Soojin Yu is currently a Senior Policy Research Officer in the Refugees Branch of Citizenship and Immigration Canada.

Lisa Roach is currently a Policy and Program Advisor in the Refugees Branch of Citizenship and Immigration Canada.

Jessie Thomson is currently a Senior Policy and Program Advisor the Refugees Branch of Citizenship and Immigration Canada.

Anmarie Harris is currently a Senior Policy Advisor in the Refugees Branch of Citizenship and Immigration Canada.

The authors would like to thank the three anonymous reviewers, Betty Robinson, Lauren Dart, Richard Jerome, and Solideva Diano for their invaluable input in this paper. The contributions to the research of staff and management from CIC, CBSA, and the IRB are also gratefully acknowledged.

Please note that the views expressed in this paper are the authors' and do not reflect Citizenship and Immigration Canada's official views. 